\title{
UNITED NATIONS CONSIDERATION OF THE USE OF SPACE NUCLEAR POWER
}

Kenneth D. Hodgkins

U.S. Department of state

Office of Advanced Technology

Room 4333

Washington, DC 20520

(202) 647-2432

Robert Lange

U.S. Department of Energy Office of Defense Energy Projects Washington, DC 20545 (301) 353-3321
Bruce C. Rashkow

U.S. Department of state office of the Legal Adviser Washington, DC 20520 (202) 647-6771

\section{Abstract}

The 53 members of the U.N. Committee on the Peaceful Uses of Outer Space have worked over the past decade to establish international standards for the development and safe operation of nuclear-powered spacecraft. Progress has been slow in coming, reflecting the technical complexity of the issue and the deep and pervasive international concern with the hazards of unplanned re-entries; however, the cosmos-1900 incident in 1988 generated a renewed interest in bringing the debate to closure as soon as possible. Since that time, significant progress has been made toward developing a set of non-binding international principles on space nuclear power. For the purposes of this paper, the authors, all of whom represent the U.S. In these negotiations, will trace the progress made to date and where the discussions are headed in the future.

\section{INTRODUCTION}

Since the $1978 \mathrm{crash}$ in Canada of the soviet nuclear powered-satellite, Cosmos 954, the U.N. Committee on the Peaceful Uses of Outer Space (COPUOS) has sought to develop, on the basis of consensus, internationally accepted principles covering the use of nuclear power in space (NPS). COPUOS' interest in this item has mounted with subsequent soviet malfunctions in 1983 (Cosmos 1402) and in 1988 (Cosmos 1900). After more than a decade of debate, a convergence of views is 
emerging on what constitutes responsible state behavior in the design and operation of space nuclear power systems. Prospects are good that copUOS will recommend non-binding principles in the form of a resolution for adoption by the General Assembly at its 46 th session in 1991 .

For the past several years, Canada and the Federal Republic of Germany (FRG), with support from the United States, have led the way in COPUOS in pressing for negotiation of principles that would encourage a higher level of safety in the conduct of space missions utilizing nuclear power and a greater measure of openness. Areas being addressed in the draft principles include the public availability of safety assessments for each launch of an NPS, guidelines and criteria for safe use of NPS, State responsibility in the event of an unplanned re-entry, compensation for damage caused by an NPS, and notification and provision of assistance to other states if future malfunctions occur. (Notification and emergency assistance are also the subject of two treaties negotiated in the International Atomic Energy Agency (IAEA) following the Chernobyl accident. These treaties apply to all nuclear accidents, including space, though they were crafted with terrestrial accidents in mind.) When eventually adopted by the General Assembly, the principles will only be recommendatory in character; under the U.N. Charter they cannot, in and of themselves, possess legal force. Nevertheless, they will constitute a useful statement of the views of the international community.

\section{DISCUSSION}

Since 1986, six of twelve draft principles have been adopted ad referendum, the most recent being at the April 1990 meeting of the Legal Sub-Committee (LSC). Principle 3, Guidelines and Criteria for Safe Use, had been a perennial source of major disagreement among the delegations technical experts. Some delegations argued for very specific and rigid guidelines for design and operation of NPS, while the United states and others insisted on a more general approach that would set safety objectives which could be met by a variety of technical solutions. However, signficant progress was made in narrowing these differences at the February 1990 Scientific and Technical Sub-Committee (STSC) which in turn laid the foundation for consensus in the LSC. This important principle sets out general goals for radiation protection and reactor and $\mathrm{RTG}$ safety taking into account concepts used in terrestrial reactors such as radiation limits suggested by the International Commission of Radiological Protection.

The more important elements of Principle 3 include the Following:

- The design for NPS shall restrict radiation exposure 
to a limited geographical region and to individuals

to a principle limit of $1 \mathrm{mSv}$ ( $1 \mathrm{mSV}=100 \mathrm{mRem}$ ) in a

year. There may be a subsidiary dose limit of $5 \mathrm{mSv}$ in a year provided that the average annual effective dose equivalent over a lifetime does not exceed $1 \mathrm{mSv}$ in a year.

- Systems important for safety shall be designed, constructed, and operated in accordance with the general concept of defense-in-depth. (Note: The U.S. has stated that for NPS this takes into account design features as well as mission operations which obviate or minimize the consequences of system malfunction and which do not automatically require redundant safety systems for each individual component.)

- The reliability of systems important for safety shall be ensured, inter alia, by redundency, physical separation, functional isolation and adequate independence of their components.

- Nuclear reactors may be operated in low earth orbits provided they are stored in a sufficiently high orbit (SHO) after the end of their operational life. An SHO is that in which the orbital lifetime is long enough to allow for a sufficient decay of the fission products to approximately the activity of the actinides. The SHO must be such that the risks to existing and future space missions and of collision with other space objects are kept to a minimum.

- For missions in an orbit with a lifetime less than in the SHO there shall be a highly reliable system to ensure an effective and controlled disposal of the reactor.

- RTGs may be used for planetary missions and in earth orbit if they are stored in a high orbit at the end of their mission.

Those other principles on which agreement has been reached can be summarized as follows:

Principle 1 - Applicability of International Law: Activities involving the use of NPS should be carried out in accordance with international law.

Principle 5 - Notification of Re-entry: Any State launching an NPS shall timely inform the U.N. Secretary-General and States concerned in the event the space object is malfunctioning with a risk of re-entry of radioactive materials to the Earth. 
Principle 6 - Consultations: States providing information in accordance with Principle 5 shall respond promptly to requests for further information or consultations sought by other states.

Princple 7 - Assistance to States: After re-entry into the Earth's atmosphere of a space object containing an NPS, the launching state shall promptly offer the necessary assistance to eliminate actual and possible harmful effects.

Principle 10 - Settlement of Disputes: Any dispute arising from the application of these principles shall be resolved through negotiations or other established procedures for the peaceful settlement of disputes.

The remaining principles cover state responsibility for the use of NPS, compensation in the event damage is caused by an NPS, public availability of safety assessments prior to each launch on an NPS, and international notification of the launch of an NPS.

For the 29th session of the LSC in 1991, the debate will most likely focus on the question of safety assessments. Most member states agree that a thorough safety assessment should be done for each launch but some have questioned the utility of making those assessments publicly available.

\section{CONCLUSION}

COPUOS and its Sub-Committee's made important progress in 1990 toward bringing to closure U.N. consideration of space nuclear power. With agreement reached on Principle 3 , a major point of contention was eliminated. However, important questions remain to be resolved through another year, at a minimum, of negotiations. The U.S. will continue to stress the importance of space nuclear power to the future of space exploration and the need to implement the highest standards of safety technologically and economically possible.

\section{Acknowledgments}

The authors wish to thank members of the staffs of the Department of State, the Department of Energy, and the National Aeronautics and Space Administration for their contributions to the preparation of this paper. 


\section{References}

Convention on Assistance in the Case of a Nuclear Accident or Radiological Emergency, September 26, 1986, Vienna.

Convention on Early Notification of a Nuclear Accident, September 26, 1986, Vienna.

Federal Republic of Germany (1989a) Use of Nuclear Power Sources in Space: Further Considerations Arising from a study of Safety Aspects of Nuclear Power Sources in Space, A/AC.105/C.1/WG.5/L.21/Add. 4, United Nations, New York, New York.

Federal Republic of Germany (1989b) Use of Nuclear Power Sources in space: Present and Future Risks of Collisions of Satelites and Manned Platforms with other space objects and Space Debris in Near Earth, A/AC.105/C.I/WG.5/L.21/Add. 6, United Nations, New York, New York.

United Kingdom (1989) Use of Nuclear Power Sources in space: An Assessment of the Risks Posed by the operation of Nuclear Power Sources in Space, A/AC.105/C.1/WG.5/L.21/Add. 3, United Nations, New York, New York.

United Nations (1979) Report of the Sixteen Session of the Scientific and Technical Sub-Committee, A/AC.105/238, United Nations, New York, New York.

United Nations (1981) Report of the Eighteenth Session of the Science and Technical Sub-Committee, A/AC.105/287, United Nations, New York, New York.

United Nations (1986) Report of the Twenty-Fifth Session of the Legal Sub-Committee, A/AC.105/370, United Nations, New York, New York.

United Nations (1989a) Report of the Twenty-Sixth Session of the Scientific and Technical sub-Committee, A/AC.105/429. United Nations, New York, New York.

United Nations (1989b), Report of the Twenty-Eighth Session of the Legal Sub-Committee, A/AC.105/430, United Nations, New York, New York.

United Nations (1990a) Report of the Twenty-Seventh Session of the Scientific and Technical Sub-Committee, A/AC.105/456, United Nations, New York, New York

United Nations (1990b) Report of the Twenty-Ninth Session of the Legal Sub-Committee, A/AC.105/457, United Nations, New York, New York. 
- DOE CONF 910116

L.C. Catalog Card No. 90-5622C

ISBN $\quad 0-88318-838-4$

$0-88318-839-2$ (pbk)

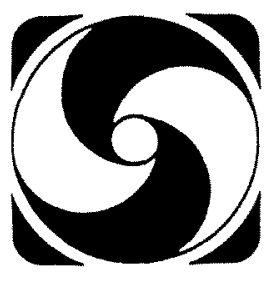

\section{PROCEEDINGS \\ OF THE EIGHTH SYMPOSIUM \\ ON SPACE NUCLEAR POWER \\ SYSTEMS}

\section{EDITORS}

Mohamed S. El-Genk

University of New Mexico

\section{Mark D. Hoover}

Lovelace Inhalation Toxicology

Research Institute

INSTTTUTE FOR SPACE NUCLEAR POWER STUDIES

Chemical and Nuclear Engineering Department

The University of New Mexico

Albuquerque, NM 87131

(505) $277-2813,277-2814$

Co-sponsored by:

NATIONAL AERONAUTICS AND SPACE ADMINISTRATION

HEADQUARTERS

LEWIS RESEARCH CENTER

STRATEGIC DEFENSE INITIATTVE ORGANIZATION

UNITED STATES DEPARTMENT OF ENERGY

ARGONNE NATIONAL LABORATORY

IDAHO NATIONAL ENGINEERING

LABORATORY

LOS ALAMOS NATIONAL LABORATORY SANDIA NATIONAL LABORATORIES

UNITED STATES AIR FORCE

SPACE TECHNOLOGY CENTER

WEAPONS LABORATORY

WRIGHT RESEARCH AND DEVELOPMENT CENTER
In cooperation with:

AMERICAN NUCLEAR SOCIETY
ANS TRINITY SECTION
ANS ENVIRONMENTAL SCIENCES DIVISION
ANS NUCLEAR REACTOR SAFETY DIVISION
AMERICAN INSTITUTE OF CHEMICAL ENGINEERS
HEAT TRANSFER AND ENERGY CONVERSION
DIVISION
AMERICAN SOCIETY OF MECHANICAL
ENGINEERS
NUCLEAR ENGINEERING DIVISION
HEAT TRANSFER DIVISION
ASTM, COMMITTEE E-1O ON NUCLEAR
TECHNOLOGY AND APPLICATIONS
INTERNATIONAL ASTRONAUTICAL FEDERATION
NEW MEXICO ACADEMY OF SCIENCE

Industry Affiliates:

BABCOCK \& WILCOX COMPANY

GENERAL ELECTRIC COMPANY

ROCKWELL INTERNATIONAL CORPORATION

ROCKETDYNE DIVISION

WESTINGHOUSE ELECTRIC CORPORATION

\footnotetext{
Albuquerque Convention Center

Albuquerque, New Mexico

January 6-10, 1991
}

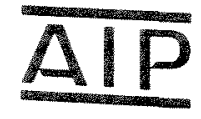

